\title{
Synthesis and Polymerization of Maleimides Containing a Cholesteryl Group
}

\author{
Tsutomu Oishi, ${ }^{*}$ Hisaki Morikawa, Koji Matsusaki, \\ and Minoru Fujimoto \\ Department of Applied Chemistry and Chemical Engineering, \\ Faculty of Engineering, Yamaguchi University, \\ 2557 Tokiwadai, Ube, Yamaguchi 755, Japan
}

(Received April 21, 1994)

\begin{abstract}
Two types of optically active $N$-(cholesteroxycarbonyl- $n$-pentyl)maleimide (ChP) and $N$-(cholesteroxycarbonyl- $n$-undecyl)maleimide $(\mathrm{ChU})$ were synthesized and polymerized with radical and anionic initiators to obtain chiral polymers. Both copolymers contained different conformations, judging from $\mathrm{CD}$ spectra. Radical copolymerizations of $\mathrm{ChP}\left(\mathrm{M}_{1}\right)$ and $\mathrm{ChU}\left(\mathrm{M}_{1}\right)$ were performed with styrene $\left(\mathrm{ST}, \mathrm{M}_{2}\right)$, methyl methacrylate $\left(\mathrm{MMA}, \mathrm{M}_{2}\right.$ ) in toluene at $60^{\circ} \mathrm{C}$. Monomer reactivity ratios $\left(r_{1}, r_{2}\right)$ and Alfrey-Price $Q-e$ were determined. Chiroptical properties for the original polymers were significantly influenced by the length of the methylene units. All hydrolyzed polymers were optically active, but specific rotations were very small.
\end{abstract}

KEY WORDS $N$-(Cholesteroxycarbonyl- $n$-pentyl)maleimide / $N$-(Cholesteroxycarbonyl- $n$-undecyl)maleimide / Optically Active Polymer / Monomer Reactivity Ratio / $Q$, e Values / Asymmetric Induction / Asymmetric Perturbation /

There are many reports on homopolymers $^{1-3}$ and copolymers ${ }^{4-6}$ with a pendant cholesteryl group. These are all related to liquid crystalline polymers, and not to polymerization reactivities of monomers containing a chiral cholesteryl moiety. Polymerizations and copolymerizations of $\mathrm{N}$-substituted maleimides (RMI) have been widely investigated. ${ }^{7}$ However, no RMI containing a cholesteryl group has been studied. Since the cholesteryl moiety is chiral and very bulky, it should be of interest to clarify the polymerization reactivities of RMI bearing cholesteryl moiety and chiroptical properties of the polymers and copolymers obtained, concerning asymmetric induction copolymerization of $c i s$-cyclic olefin and asymmetric perturbation of the chiral side chain chromophore. Recently we reported ${ }^{8}$ the polymerizabilities of $\mathrm{N}$-(cholesteroxycarbon- ylmethyl)maleimide (ChM) $(n=1$ in Scheme 1) and chiroptical properties of polymers and copolymers. Specific rotations and circular dichroism (CD) spectra for the copolymers could be ascribed to chiral maleimide repeat units and comonomer units. It was suggested that asymmetric induction into the homopolymer and copolymer main chains took place judging from chiroptical properties for a model compound of poly(ChM).

In this study, novel, optically active $N$ (cholesteroxycarbonyl- $n$-pentyl)maleimide (ChP) and $N$-(cholesteroxycarbonyl- $n$-undecyl)maleimide $(\mathrm{ChU})$ were synthesized from maleic anhydride, 6-amino- $n$-caproic acid (or 12-amino- $n$-dodecanoic acid) and cholesterol. $\mathrm{ChP}$ and $\mathrm{ChU}$ were polymerized and copolymerized with styrene (ST) and methyl methacrylate (MMA) in the presence of a radical

\footnotetext{
* To whom all correspondence should be addressed.
} 
initiator. Monomer reactivity ratios and $Q, e$ were determined. Based on the specific rotations and molecular ellipticities of the copolymers, asymmetric induction into the copolymer main chain and asymmetric perturbation of side chain chromophore are discussed, compared with that of $\mathrm{ChM}^{8}$ ( $n=1$ in Scheme 1). ChP and ChU are also polymerized with an anionic initiator; $n$ - $\mathrm{BuLi}$, to obtain a chiral polymer, whose chiroptical properties were compared with those for the polymers obtained from radical initiators.

\section{EXPERIMENTAL}

ChP and ChU Monomers

$N$-(5-Carboxy- $n$-pentyl)maleimide (CPMI) and $N$-(11-carboxy- $n$-undecyl)maleimide (CUMI) were synthesized, according to a method reported previously, ${ }^{9}$ with some modification. ${ }^{10} \mathrm{ChP}$ and $\mathrm{ChU}$ were synthesized from CPMI (or CUMI) and cholesterol, as shown in Scheme 1.

$N$-(5-Carboxy-n-pentyl)maleamic Acid (CPMA). CPMA was synthesized from maleic

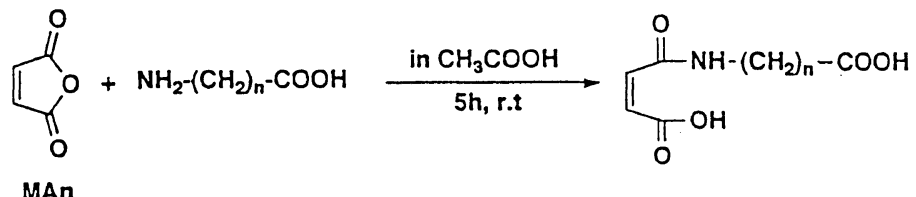<smiles>CCCCCCCN1C(=O)C=CC1=O</smiles>

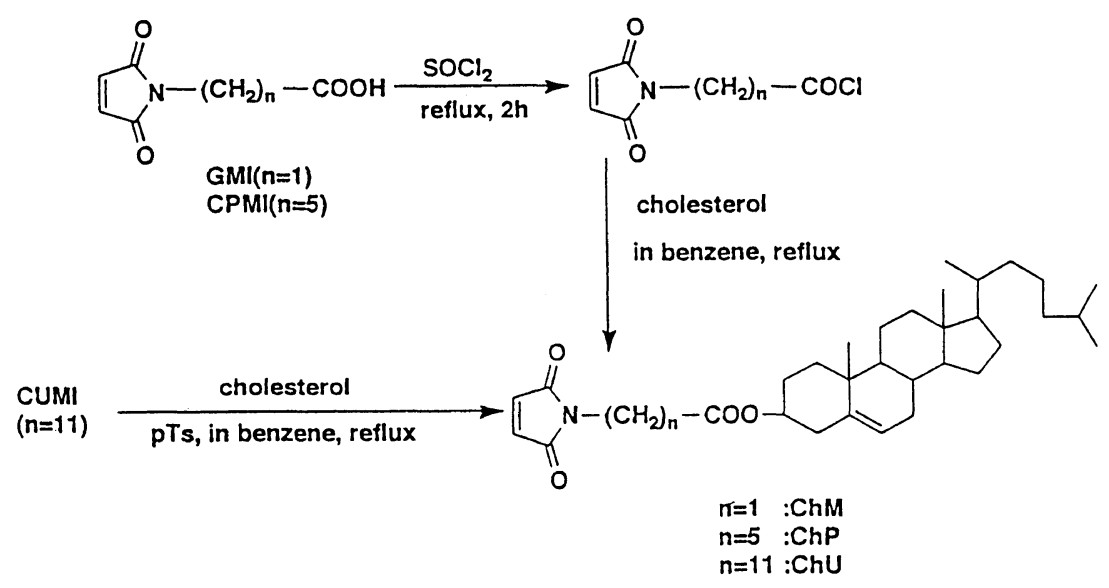

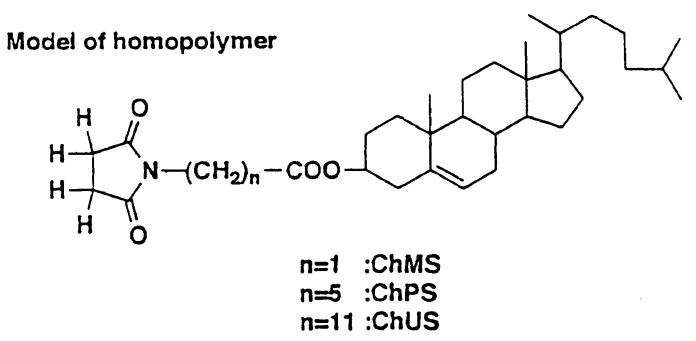

Scheme 1. 
anhydride (MAn) and 6-amino- $n$-caproic acid in acetic acid at room temperature; yield $86.5 \%$; mp $158.5-160^{\circ} \mathrm{C}$ [lit. ${ }^{9} 159.5-161^{\circ} \mathrm{C}$ ]. ${ }^{1} \mathrm{H}$ NMR: chemical shift, $\delta$, ppm from tetramethylsilane (TMS) in deuterium dimethyl sulfoxide (DMSO- $\left.d_{6}\right)$ : $9.05(\mathrm{~m}, 1 \mathrm{H}, \mathrm{NH}), 6.65$ $(2 \mathrm{~d}, J=12.1 \mathrm{~Hz}, 2 \mathrm{H}, \mathrm{CH}=\mathrm{CH}), 2.48(\mathrm{~m}, 2 \mathrm{H}$, $\left.\mathrm{N}-\mathrm{CH}_{2}\right), 2.20\left(\mathrm{t}, J=4.8 \mathrm{~Hz}, 2 \mathrm{H}, \mathrm{COCH}_{2}\right), 1.35$ (m, $6 \mathrm{H}, \mathrm{CH}_{2} \mathrm{CH}_{2} \mathrm{CH}_{2}$ ).

$N$-(5-Carboxy-n-pentyl)maleimide $(C P M I) .{ }^{10}$ CPMI was prepared by the dehydration of CPMA in the presence of triethylamine in xylene; yield $31.3 \%$; mp $82-83^{\circ} \mathrm{C}$ [lit. ${ }^{9}$ $\left.79-80^{\circ} \mathrm{C}\right] .{ }^{1} \mathrm{H}$ NMR $(\delta, \mathrm{ppm}$ from TMS in $\left.\mathrm{CDCl}_{3}\right): 6.70(\mathrm{~s}, 2 \mathrm{H}, \mathrm{CH}=\mathrm{CH}) ; 3.52(\mathrm{t}$, $\left.J=7.3 \mathrm{~Hz}, 2 \mathrm{H}, \mathrm{N}-\mathrm{CH}_{2}\right), 2.35(\mathrm{t}, J=7.3 \mathrm{~Hz}, 2 \mathrm{H}$, $\left.\mathrm{COCH}_{2}\right), 1.72-1.56\left(\mathrm{~m}, 4 \mathrm{H}, \mathrm{N}-\mathrm{CH}_{2}-\mathrm{CH}_{2}\right.$ and $\mathrm{OOCCH}_{2}-\mathrm{CH}_{2}$ ), and $1.40-1.31(\mathrm{~m}, 2 \mathrm{H}$, $\left.\mathrm{CH}_{2}\right)$.

$N$-[5-(Chlorocarbonyl)-n-pentyl]maleimide (CCPMI). CPMI was treated with thionyl chloride to obtain CCPMI: bp $142-143^{\circ} \mathrm{C} /$ $3.6 \times 10^{-2} \mathrm{mmHg}$; yield $73.9 \%$. ${ }^{1} \mathrm{H}$ NMR $(\delta$, ppm from TMS in $\left.\mathrm{CDCl}_{3}\right): 6.70(\mathrm{~s}, 2 \mathrm{H}$, $\mathrm{CH}=\mathrm{CH}), 3.50\left(\mathrm{t}, J=6.0 \mathrm{~Hz}, 2 \mathrm{H}, \mathrm{N}-\mathrm{CH}_{2}\right)$, $2.88\left(\mathrm{t}, J=6.0 \mathrm{~Hz}, 2 \mathrm{H}, \mathrm{CH}_{2} \mathrm{COCl}\right)$, and 1.48 $\left(\mathrm{m}, 6 \mathrm{H}, \mathrm{CH}_{2} \mathrm{CH}_{2} \mathrm{CH}_{2}\right.$ ).

$N$-(5-Cholesteroxycarbonyl-n-pentyl)maleimide $(C h P)$. A solution of CCPMI $(27.9 \mathrm{~g}$, $0.16 \mathrm{~mol}$ ) in $100 \mathrm{ml}$ of benzene was added dropwise to $200 \mathrm{ml}$ of benzene solution dissolved cholesterol $(62.3 \mathrm{~g}, 0.16 \mathrm{~mol})$ and $N, N$-dimethylaniline $(0.1 \mathrm{~g}, 0.82 \mathrm{mmol})$. The solution was stirred and refluxed for $12 \mathrm{~h}$. The reaction was performed under nitrogen atmosphere. The reaction mixture was poured into $100 \mathrm{ml}$ of ice water containing $2 \mathrm{ml}$ of hydrochloric acid. The solution was extracted with chloroform to obtain crude ChP. The chloroform solution was evaporated to dryness, and benzene was added. The product was isolated by column chromatography on alumina, using benzene as eluent, and then recrystallized from hexane to obtain pure ChP (76 g, 56\% based on CCPMI; total yield $11.2 \%): \mathrm{mp} 99-101^{\circ} \mathrm{C} ;[\alpha]_{\mathrm{D}}=-22.1^{\circ}(c=$
$1.0 \mathrm{~g} \mathrm{dl}^{-1} ; l=10 \mathrm{~cm}$; tetrahydrofuran (THF)).

IR ( $\mathrm{KBr}$ disk, $\left.\mathrm{cm}^{-1}\right): 2840\left(\mathrm{CH}, \mathrm{CH}_{2}, \mathrm{CH}_{3}\right)$, 1730 and $1695(\mathrm{CO}-\mathrm{N}-\mathrm{CO}), 1675(\mathrm{C}=\mathrm{C}), 1465$, 1404, and $1370\left(\mathrm{CH}, \mathrm{CH}_{2}, \mathrm{CH}_{3}\right), 1235$ and $1170(\mathrm{OC}=\mathrm{O}), 830$ and $695($ cis $\mathrm{CH}=\mathrm{CH}) .{ }^{1} \mathrm{H}$ NMR $(\delta, \mathrm{ppm}$ from tetramethylsilane (TMS) in $\left.\mathrm{CDCl}_{3}\right): 6.67(\mathrm{~s}, 2 \mathrm{H}, \mathrm{CH}=\mathrm{CH}) ; 5.38-5.36$ $(\mathrm{m}, 1 \mathrm{H}, \mathrm{CH}=\mathrm{C}$ in cholesteryl), $4.64-4.53(\mathrm{~m}$, $1 \mathrm{H}, \mathrm{O}-\mathrm{CH}$ in cholesteryl), $3.51(\mathrm{t}, J=7.0 \mathrm{~Hz}$, $\left.2 \mathrm{H}, \quad \mathrm{N}-\mathrm{CH}_{2}\right), 2.31-0.67(\mathrm{~m}, 51 \mathrm{H}$, other protons of cholesteryl and $n$-pentyl groups). ${ }^{13} \mathrm{C}$ NMR spectra $(\delta$, ppm from TMS in $\left.\mathrm{CDCl}_{3}\right): 172.70(\mathrm{COO}), 170.67(\mathrm{CO}-\mathrm{N}-\mathrm{CO})$, $139.72(-\mathrm{C}=$ in cholesteryl), $134.01(\mathrm{C}=\mathrm{C}$ in maleimide), 122.55 (= $\mathrm{CH}-$ in cholesteryl), $73.82(\mathrm{O}-\mathrm{CH}$ in cholesteryl), 56.76, 56.25, $50.14,42.39,39.83,39.56,38.20,37.71,37.07$, $36.66,36.24,35.80,34.45,31.96,28.23,28.01$, $27.88,26.25,24.55,24.31,23.89,22.79,22.55$, $21.11,19.33,18.76,11.90$ (29C, other carbons of both cholesteryl and $n$-pentyl).

Elemental Analysis. Found: $\mathrm{C}=76.35 \% ; \mathrm{H}=$ $10.03 \% ; \mathrm{N}=2.66 \%$. Calcd for $\mathrm{C}_{37} \mathrm{H}_{57} \mathrm{O}_{4} \mathrm{~N}$ : $\mathrm{C}=76.62 \% ; \mathrm{H}=9.93 \% ; \mathrm{N}=2.42 \%$.

$N$-(11-Carboxy-n-undecyl)maleamic Acid (CUMA). Yield $77.3 \%, \mathrm{mp} 149-151^{\circ} \mathrm{C}$ (lit. ${ }^{9}$ $\left.152-153^{\circ} \mathrm{C}\right) .{ }^{1} \mathrm{H}$ NMR $(\delta, \mathrm{ppm}$ from TMS in $N$-dimethylsulfoxide DMSO- $\left.d_{6}\right): 9.12(\mathrm{~m}, 1 \mathrm{H}$, $\mathrm{NH}), 8.65-7.81(\mathrm{~m}, 2 \mathrm{H}, 2 \mathrm{COOH}), 6.32(2 \mathrm{~d}$, $J=12.1 \mathrm{~Hz}, 2 \mathrm{H}, \mathrm{CH}=\mathrm{CH}), 3.15(\mathrm{t}, J=7.3 \mathrm{~Hz}$, $\left.2 \mathrm{H}, \mathrm{N}-\mathrm{CH}_{2}\right), 2.18\left(\mathrm{t}, J=7.4 \mathrm{~Hz}, 2 \mathrm{H}, \mathrm{CH}_{2}-\right.$ $\mathrm{COO}), 1.63-1.52\left(\mathrm{~m}, 4 \mathrm{H}, \mathrm{N}-\mathrm{CH}_{2}-\mathrm{CH}_{2}\right.$ and $\left.\mathrm{OOCCH}_{2}-\mathrm{CH}_{2}\right)$, and $1.23\left(\mathrm{~m}, 14 \mathrm{H},\left(\overline{\mathrm{CH}}_{2}\right)_{7}\right)$.

$N$-(11- $\overline{\text { Carboxy-n-undecyl) maleimide }}$ $(C U M I) .{ }^{10}$ Yield $20.0 \%$, mp $89-91^{\circ} \mathrm{C}$ (lit. ${ }^{9}$ mp $\left.81-84^{\circ} \mathrm{C}\right){ }^{1} \mathrm{H}$ NMR $(\delta$, ppm from TMS in $\mathrm{CDCl}_{3}: 6.69(\mathrm{~s}, 2 \mathrm{H}, \mathrm{CH}=\mathrm{CH}), 3.50(\mathrm{t}$, $\left.J=7.3 \mathrm{~Hz}, 2 \mathrm{H}, \mathrm{N}-\mathrm{CH}_{2}\right), 2.34(\mathrm{t}, J=7.4 \mathrm{~Hz}$, $\left.2 \mathrm{H}, \mathrm{CH}_{2} \mathrm{COO}\right), 1.65-1.55\left(\mathrm{~m}, 4 \mathrm{H}, \mathrm{N}-\mathrm{CH}_{2}-\right.$ $\mathrm{CH}_{2}$ and $\left.\mathrm{OOCCH}_{2}-\mathrm{CH}_{2}\right)$, and $1.26(\mathrm{~m}, 14 \mathrm{H}$, $\left.\left(\mathrm{CH}_{2}\right)_{7}\right)$.

$C h U$. ChU was synthesized from CUMI and cholesterol in the presence of $p$-toluenesulfonic acid (pTs). A mixture of CUMI ( $5 \mathrm{~g}$, $0.017 \mathrm{~mol})$, cholesterol $(9.8 \mathrm{~g}, 0.026 \mathrm{~mol})$, and pTs $\left(0.65 \mathrm{~g}, 2.4 \times 10^{-3} \mathrm{~mol}\right)$ in benzene $(50 \mathrm{ml})$ 
was refluxed for $24 \mathrm{~h}$. On completion of the reaction, the reaction mixture was evaporated to dryness, and chloroform $(100 \mathrm{ml})$ was added. The chloroform solution was washed with water three times, and the organic layer was dried with magnesium sulfate. The chloroform solution was evaporated to dryness, and benzene was added. The product was isolated by column chromatography on alumina, using benzene as the eluent, and then recrystallized from ethanol to obtain pure $\mathrm{ChU}(4.7 \mathrm{~g}$, yield $42.0 \%$ based on CUMI; total yield $(6.5 \%): \mathrm{mp}$ $64-66^{\circ} \mathrm{C} ;[\alpha]_{\mathrm{D}}=-18.9^{\circ} \quad\left(c=1.0 \mathrm{~g} \mathrm{dl}^{-1} ; l=\right.$ $10 \mathrm{~cm}$; THF). IR(KBr disk, $\left.\mathrm{cm}^{-1}\right): 2830(\mathrm{CH}$, $\left.\mathrm{CH}_{2}, \mathrm{CH}_{3}\right), 1730$ and 1701 (CO-N-CO), 1675 $(\mathrm{C}=\mathrm{C}), 1465,1405$, and $1365\left(\mathrm{CH}, \mathrm{CH}_{2}, \mathrm{CH}_{3}\right)$, $1170(\mathrm{OC}=\mathrm{O}), 835$ and 692 ( cis $\mathrm{CH}=\mathrm{CH}) .{ }^{1} \mathrm{H}$ NMR $\left(\delta\right.$, ppm from TMS in $\left.\mathrm{CDCl}_{3}\right): 6.68$ (s, $2 \mathrm{H}, \mathrm{CH}=\mathrm{CH}) ; 5.37-5.24(\mathrm{~m}, 1 \mathrm{H}, \mathrm{CH}=\mathrm{C}$ in cholesteryl), 4.67-4.55 (m, $1 \mathrm{H}, \mathrm{O}-\mathrm{CH}$ in cholesteryl), $3.52\left(\mathrm{t}, J=7.3 \mathrm{~Hz}, 2 \mathrm{H}, \mathrm{N}-\mathrm{CH}_{2}\right)$, $2.36-0.62(\mathrm{~m}, 63 \mathrm{H}$, other protons of cholesteryl and $n$-undecyl groups). ${ }^{13} \mathrm{C}$ NMR ( $\delta$, ppm from TMS in $\mathrm{CDCl}_{3}$ ): 173.29 (COO), 170.89 (CO-N-CO), $139.75(-\mathrm{C}=$ in cholesteryl), $134.03(\mathrm{C}=\mathrm{C}$ in maleimide), $122.59(=\mathrm{CH}-$ in cholesteryl), 73.67 (O-CH in cholesteryl), 56.71, 56.15, 50.04, 42.32, 39.74, 39.53, 38.18, $37.93,37.02,36.60,36.21,35.81,34.72,31.91$, $31.88,29.45,29.40,29.24,29.11,28.53,28.25$, $28.01,27.83,26.74,25.07,24.29,23.85,22.82$, $22.57,21.04,19.33,18.72,11.86$ (35C, other carbons of both cholesteryl and $n$-undecyl groups).

Elemental Analysis. Found: $\mathrm{C}=77.96 \%$; $\mathrm{H}=9.27 \% ; \mathrm{N}=2.40 \%$. Calcd for $\mathrm{C}_{43} \mathrm{H}_{69} \mathrm{O}_{4} \mathrm{~N}$ : $\mathrm{C}=77.78 \% ; \mathrm{H}=8.97 \% ; \mathrm{N}=2.11 \%$.

Model Compound of Poly $(\mathrm{ChP}): \mathrm{N}$-(Cholesteroxycarbonyl-n-pentyl)succinimide (ChPS)

ChPS was prepared from succinic anhydride, 6-aminocaproic acid, and cholesterol, according to a method similar to that of ChP. Yields and melting points of precursors are as follows: $N$-(5-carboxy- $n$-pentyl)succinamic acid: yield $70.7 \%$; mp $100-101^{\circ} \mathrm{C} ; N$ - $(5$-carboxy- $n$-pen- tyl)succinimide: yield $32 \%, \mathrm{mp} 79-81^{\circ} \mathrm{C}, \mathrm{N}-$ (5-chlorocarbonyl- $n$-pentyl)succinimide: yield $85 \%, \mathrm{mp} 162-163^{\circ} \mathrm{C} / 3.4 \times 10^{-2} \mathrm{mmHg}$.

ChPS. ChPS was recrystallized from hexane: total yield $11.5 \% ; \mathrm{mp} 98-100^{\circ} \mathrm{C} ;[\alpha]_{\mathrm{D}}=$ $-21.3^{\circ}\left(c=1.0 \mathrm{~g} \mathrm{dl}^{-1}, l=10 \mathrm{~cm}, \mathrm{THF}\right)$. IR ( $\mathrm{KBr}$ disk, $\left.\mathrm{cm}^{-1}\right): 2890\left(\mathrm{CH}_{2}\right.$ and $\left.\mathrm{CH}_{3}\right), 1730$ and $1700(\mathrm{CO}-\mathrm{N}-\mathrm{CO}), 1400$ and $1375\left(\mathrm{CH}_{3}\right)$, 1180 and $1145(\mathrm{OC}=\mathrm{O}) .{ }^{1} \mathrm{H}$ NMR $(\delta, \mathrm{ppm}$ from TMS in $\left.\mathrm{CDCl}_{3}\right)$ : $5.37-5.34(\mathrm{~m}, 1 \mathrm{H}$, $\mathrm{CH}=\mathrm{C}$ in cholesteryl), $4.63-4.54(\mathrm{~m}, 1 \mathrm{H}$, $\mathrm{O}-\mathrm{CH}$ in cholesteryl), $3.53(\mathrm{t}, J=7.0 \mathrm{~Hz}, 2 \mathrm{H}$, $\left.\mathrm{N}-\mathrm{CH}_{2}\right), 2.69\left(\mathrm{~s}, 4 \mathrm{H}, \mathrm{CH}_{2}-\mathrm{CH}_{2}\right), 2.32-0.66$ $(\mathrm{m}, 51 \mathrm{H}$, other protons of cholesteryl and $n$-pentyl groups). ${ }^{13} \mathrm{C}$ NMR spectra $(\delta, \mathrm{ppm}$ from TMS in $\left.\mathrm{CDCl}_{3}\right)$ : $177.27(\mathrm{CO}-\mathrm{N}-\mathrm{CO})$, 173.31 (COO), 139.75 ( $-\mathrm{C}=$ in cholesteryl), 122.59 ( = CH-in cholesteryl), $73.69(\mathrm{O}-\mathrm{CH}$ in cholesteryl), $36.08\left(\mathrm{CH}_{2}-\mathrm{CH}_{2}\right.$ in succinimide), and 56.76, 56.24, 50.13, 42.39, 39.84, 39.57, $38.20,37.72,37.07,36.66,36.25,35.81,34.45$, $31.96,28.22,28.01,27.89,26.25,24.55,24.32$, $23.90,22.79,22.55,21.12,19.33,18.76,11.89$ (29C, other carbons of both cholesteryl and $n$-pentyl).

Elemental Analysis. Found: $\mathrm{C}=76.62 \% ; \mathrm{H}=$ $10.08 \% ; \mathrm{N}=2.59 \%$. Calcd for $\mathrm{C}_{37} \mathrm{H}_{59} \mathrm{O}_{4} \mathrm{~N}$ : $\mathrm{C}=76.37 \% ; \mathrm{H}=10.22 \% ; \mathrm{N}=2.41 \%$.

Model Compound of Poly $(\mathrm{ChU})$ : N-(Cholesteroxycarbonyl-n-undecyl)succinimide (ChUS)

ChUS was prepared from succinic anhydride, 12-amino- $n$-dodecanoic acid and cholesterol in a manner similar to that of $\mathrm{ChU}$. Yields and melting points of precursors are as follows: $N$-(11-carboxy- $n$-undecyl)succinamic acid: yield $98 \%$; mp $150-153^{\circ} \mathrm{C} ; \mathrm{N}-(11-$ carboxyundecyl)succinimide: yield $63 \%, \mathrm{mp}$ $111-116^{\circ} \mathrm{C}$.

ChUS. Total yield $12.6 \%$ mp $72-74^{\circ} \mathrm{C}$; $[\alpha]_{\mathrm{D}}=-19.4^{\circ}\left(c=1.0 \mathrm{~g} \mathrm{dl}^{-1}, l=10 \mathrm{~cm}, \mathrm{THF}\right)$. IR ( $\mathrm{KBr}$ disk, $\left.\mathrm{cm}^{-1}\right): 2900\left(\mathrm{CH}_{2}\right.$ and $\left.\mathrm{CH}_{3}\right)$, 1725 and $1695(\mathrm{CO}-\mathrm{N}-\mathrm{CO}), 1460,1400$, and $1370\left(\mathrm{CH}_{3}\right.$ and $\left.\mathrm{CH}_{2}\right), 1180$ and $1145(\mathrm{OC}=\mathrm{O})$. ${ }^{1} \mathrm{H}$ NMR $\left(\delta, \mathrm{ppm}\right.$ from TMS in $\left.\mathrm{CDCl}_{3}\right)$ : $5.38-5.24(\mathrm{~m}, 1 \mathrm{H}, \mathrm{CH}=\mathrm{C}$ in cholesteryl), 
4.67-4.55 (m, $1 \mathrm{H}, \mathrm{O}-\mathrm{CH}$ in cholesteryl), 3.49 (t, $\left.J=7.6 \mathrm{~Hz}, 2 \mathrm{H}, \mathrm{N}-\mathrm{CH}_{2}\right), 2.69(\mathrm{~s}, 4 \mathrm{H}$, $\mathrm{CH}_{2}-\mathrm{CH}_{2}$ in succinimide), $2.32-0.62(\mathrm{~m}, 63 \mathrm{H}$, other protons of cholesteryl and $n$-pentyl groups). ${ }^{13} \mathrm{C}$ NMR $(\delta$, ppm from TMS in $\left.\mathrm{CDCl}_{3}\right)$ : $177.27(\mathrm{CO}-\mathrm{N}-\mathrm{CO}), 173.29(\mathrm{COO})$, $139.75(-\mathrm{C}=$ in cholesteryl $), 122.59(=\mathrm{CH}-$ in cholesteryl), 73.69 (O- $\mathrm{CH}$ in cholesteryl), 36.08 $\left(\mathrm{CH}_{2}-\mathrm{CH}_{2}\right.$ in succinimide), and $56.71,56.15$, 50.04, 42.32, 39.74, 39.53, 38.16, 37.93, 37.02, $36.60,36.19,35.79,34.72,31.91,31.88,29.47$, $29.43,29.24,29.14,28.23,28.15,28.01,27.83$, $26.73,25.07,24.29,23.85,22.82,22.57,21.04$, $19.33,18.72,11.86$ (35C, other carbons of cholesteryl and $n$-undecyl).

Elemental Analysis. Found: $\mathrm{C}=76.48 \% ; \mathrm{H}=$ $10.55 \% ; \mathrm{N}=2.35 \%$. Calcd for $\mathrm{C}_{43} \mathrm{H}_{71} \mathrm{O}_{4} \mathrm{~N}$ : $\mathrm{C}=77.54 \% ; \mathrm{H}=10.75 \% ; \mathrm{N}=2.10 \%$.

\section{Other Materials}

Styrene (ST), methyl methacrylate (MMA), benzene (BEN), tetrahydrofuran (THF), toluene (TOL) and other solvents were purified by the usual methods. 2,2'-Azobisisobutyronitrile (AIBN) was purified by recrystallization twice from methanol, while commercially available $n$-butyllithium ( $n$-BuLi) hexane solution was used without further purification.

\section{Homopolymerization and Copolymerization}

Radical homopolymerization and copolymerization were carried out with AIBN as the initiator in THF, benzene (BEN), toluene (TOL), cyclohexane (CHX), o-xylene (o-X), chloroform (CF), chlorobenzene (CB), dichlorobenzene (DCB) or dioxane (DOX) in a sealed tube at $60^{\circ} \mathrm{C}$. After polymerization, the polymer solution was poured into excess hexane/acetone $(1 / 1)$ to precipitate the polymer. The obtained polymer was purified by reprecipitation from the THF solution to hexane/acetone $(1 / 1)$ three times. The polymer was filtered and dried in vacuo for 3 days at $40^{\circ} \mathrm{C}$. The composition of the copolymer obtained was calculated by ${ }^{1} \mathrm{H}$ NMR spectra and elemental analysis $(N)$.

Anionic homopolymerization was achieved in toluene or THF at $0^{\circ} \mathrm{C}$ using $n$-butyllithium ( $n$-BuLi) as a catalyst under a nitrogen atmosphere. The polymerization was terminated with a few drops of methanol using a syringe. The solution was poured into excess hexane/acetone $(1 / 1)$. The obtained polymer was purified by reprecipitation three times from the THF solution to hexane/acetone $(1 / 1)$, filtered and dried in vacuo at $40^{\circ} \mathrm{C}$.

\section{Hydrolysis of the Polymers and Copolymers}

A mixture of the polymers and copolymers $(0.1 \mathrm{~g})$ in THF $(100 \mathrm{ml})$ and methanol $(100 \mathrm{ml})$ saturated with potassium hydroxide was refluxed for $72 \mathrm{~h}$. The solvents in the reaction mixture were completely evaporated out, and $200 \mathrm{ml}$ of water were added to the residue. The solution $\mathrm{pH}$ was changed to $3-4$ by $12 \mathrm{~N}$ hydrochloric acid to precipitate the hydrolyzed polymers. The precipitate was filtered and dried. For the ST copolymers, the precipitate was washed with ether to remove cholesterol. For the homopolymers and MMA copolymers, the precipitate was completely dissolved in ether and was found to be only cholesterol based on NMR spectra. Thus, the water in the filtrate was evaporated out. Extraction of the residue with acetone gave the hydrolyzed polymer. It was filtered and dried. All products were reprecipitated from the methanol solution into a large amount of diethyl ether, filtered and dried. The hydrolyzed polymers were identified from their NMR spectra.

\section{Measurements}

D-line specific rotations, optical rotatory dispersion (ORD), circular dichroism (CD) spectra and molecular weights of polymers were measured, as reported previously. ${ }^{8}$ IR and NMR spectra were obtained and elemental analysis was carried out, as done previously. ${ }^{8}$ 


\section{RESULTS AND DISCUSSION}

Radical and Anionic Homopolymerization of $\mathrm{ChP}$ and $\mathrm{ChU}$

Radical and anionic polymerizations of $\mathrm{ChP}$ and $\mathrm{ChU}$ were performed under various conditions. The results are shown in Tables I and II. The polymerizations proceeded homogeneously throughout. The obtained polymers were colorless powders with negative optical activ-

Table I. Homopolymerizations of $\mathrm{ChP}$

\begin{tabular}{|c|c|c|c|c|c|c|c|c|c|c|c|}
\hline \multirow{2}{*}{ Run } & $\mathrm{ChP}$ & Initiator & $\begin{array}{l}\text { Polymr. } \\
\text { Solvent }^{\mathrm{a}}\end{array}$ & $\begin{array}{c}\text { Polymr. } \\
\text { temp. }\end{array}$ & $\begin{array}{l}\text { Polymr. } \\
\text { time }\end{array}$ & Convn. & $N$-Anal. & $\bar{M}_{n}^{\mathrm{b}}$ & \multirow{2}{*}{$\bar{M}_{n} / \bar{M}_{w}$} & \multirow{2}{*}{$\frac{[\alpha]_{\mathrm{D}}^{25^{\mathrm{c}}}}{\operatorname{deg}}$} & \multirow{2}{*}[\theta]{$_{\lambda}{ }^{\mathrm{d}}$} \\
\hline & $\times 10^{3} \mathrm{~mol}$ & $\times 10^{-2} \mathrm{moll}^{-1}$ & $\mathrm{ml}$ & ${ }^{\circ} \mathrm{C}$ & $\mathrm{h}$ & $\%$ & $\%$ & $\times 10^{-4}$ & & & \\
\hline $1-1$ & 1.00 & AIBN (1.0) & BEN (1) & 60 & 24 & 50.9 & - & 3.53 & 2.7 & -22.6 & - \\
\hline $1-2$ & 1.00 & AIBN (1.0) & TOL (1) & 60 & 24 & 50.5 & - & 1.30 & 2.8 & -22.8 & -1110 \\
\hline $1-3$ & 1.00 & AIBN (1.0) & $o-\mathrm{X}(1)$ & 60 & 24 & 53.3 & 2.34 & 1.93 & 1.3 & -22.4 & -665 \\
\hline $1-4$ & 1.00 & AIBN (1.0) & THF (1) & 60 & 24 & 47.9 & 2.36 & 0.96 & 1.5 & -22.0 & - \\
\hline $1-5$ & 1.00 & AIBN (1.0) & DOX (1) & 60 & 24 & 45.1 & 2.77 & 8.07 & 2.1 & -22.5 & -607 \\
\hline $1-6$ & 1.00 & AIBN (1.0) & CF (1) & 60 & 24 & 20.7 & 2.47 & 1.27 & 1.1 & -21.4 & -1120 \\
\hline $1-7$ & 1.00 & AIBN (1.0) & DCB (1) & 60 & 24 & 48.5 & 2.72 & 3.05 & 1.4 & -22.5 & - \\
\hline $1-8$ & 0.93 & DBPO $(9.2)^{e}$ & Bulk & 120 & 24 & 60.6 & 一 & 4.37 & 1.5 & -22.6 & -661 \\
\hline $1-9$ & 1.50 & $n$-BuLi (4.6) & TOL (2) & 0 & 18 & 58.8 & 2.44 & 2.29 & 2.3 & -24.4 & -942 \\
\hline $1-10$ & 1.50 & $n$-BuLi (4.6) & THF (2) & 0 & 18 & 41.2 & 2.49 & 1.56 & 1.6 & -22.7 & -413 \\
\hline
\end{tabular}

a BEN, benzene; TOL, toluene; $o$-X, $o$-xylene; THF, tetrahydrofuran; DOX, dioxane; CF, chloroform; DBC, dichlorobenzene

b By GPC.

c $c=1.0 \mathrm{~g} \mathrm{dl}^{-1}, l=5 \mathrm{~cm}$, THF.

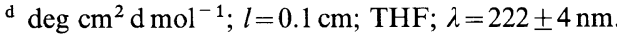

e Di-tert-butyl peroxide; $9.2 \times 10^{-5} \mathrm{~mol}$.

Table II. Homopolymerizations of ChU

\begin{tabular}{|c|c|c|c|c|c|c|c|c|c|c|c|}
\hline \multirow{2}{*}{ Run } & $\mathrm{ChU}$ & Initiator & $\begin{array}{l}\text { Polymr. } \\
\text { Solvent }^{\mathrm{a}}\end{array}$ & $\begin{array}{c}\text { Polymr. } \\
\text { temp. }\end{array}$ & $\begin{array}{l}\text { Polymr. } \\
\text { time }\end{array}$ & Convn. & $N$-Anal. & $\bar{M}_{n}^{\mathrm{b}}$ & \multirow{2}{*}{$\bar{M}_{n} / \bar{M}_{w}$} & \multirow{2}{*}{$\frac{[\alpha]_{\mathrm{D}}^{25^{\mathrm{c}}}}{\operatorname{deg}}$} & \multirow{2}{*}[\theta]{$_{\lambda}^{\mathbf{d}}$} \\
\hline & $\times 10^{3} \mathrm{~mol}$ & $\times 10^{-2} \mathrm{moll}^{-1}$ & $\mathrm{ml}$ & ${ }^{\circ} \mathrm{C}$ & $\mathrm{h}$ & $\%$ & $\%$ & $\times 10^{-4}$ & & & \\
\hline $2-1$ & 1.00 & AIBN (1.0) & BEN (1) & 60 & 24 & 48.1 & 2.33 & 1.51 & 1.4 & -18.8 & -1299 \\
\hline $2-2$ & 1.00 & AIBN (1.0) & TOL (1) & 60 & 24 & 43.9 & 2.38 & 1.46 & 2.7 & -18.7 & -938 \\
\hline $2-3$ & 1.00 & AIBN (1.0) & $o-\mathrm{X}(1)$ & 60 & 24 & 36.1 & - & 0.90 & 1.5 & -17.3 & - \\
\hline $2-4$ & 1.00 & AIBN (1.0) & THF (1) & 60 & 24 & 38.3 & - & 0.96 & 1.5 & -18.2 & -699 \\
\hline $2-5$ & 1.00 & AIBN (1.0) & $\mathrm{CHX}(2)$ & 60 & 24 & 22.1 & 2.21 & 1.10 & 1.6 & -17.5 & - \\
\hline $2-6$ & 1.00 & AIBN (1.0) & DOX (1) & 60 & 24 & 38.7 & 2.38 & 1.01 & 1.8 & -18.4 & - \\
\hline $2-7$ & 1.00 & AIBN (1.0) & CF (1) & 60 & 24 & 42.5 & - & 1.50 & 1.9 & -18.8 & -1123 \\
\hline $2-8$ & 0.93 & $\operatorname{PBPV}(5.3)^{\mathrm{e}}$ & Bulk & 70 & 24 & 77.9 & 2.40 & - & - & - & - \\
\hline $2-9$ & 1.50 & $n$-BuLi (3.8) & TOL (2) & 0 & 18 & 78.0 & 2.33 & 1.10 & 2.6 & -19.4 & -467 \\
\hline $2-10$ & 1.50 & $n$-BuLi (3.8) & THF (2) & 0 & 18 & 90.8 & - & 1.20 & 2.1 & -19.2 & -579 \\
\hline
\end{tabular}

a BEN, benzene; TOL, toluene; $o-\mathrm{X}, o$-xylene; THF, tetrahydrofuran; CHX, cyclohexane; DOX, dioxane; CF, chloroform.

b By GPC.

c $c=1.0 \mathrm{~g} \mathrm{dl}^{-1}, l=5 \mathrm{~cm}, \mathrm{THF}$.

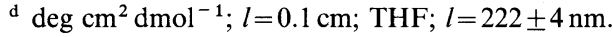

e tert-butyl peroxy pivalate; $5.3 \times 10^{-5} \mathrm{~mol}$. 


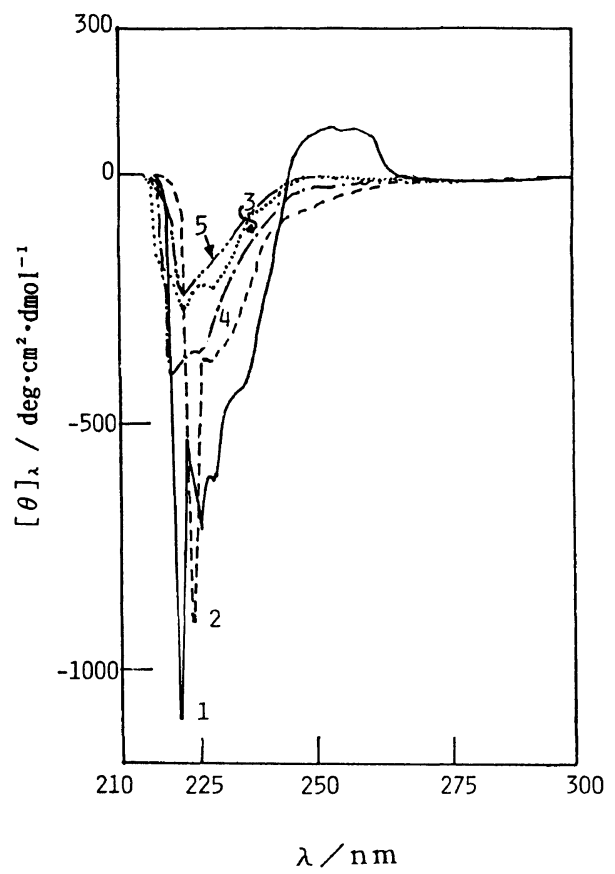

Figure 1. CD spectra $\left(c=0.1-0.01 \mathrm{~g} \mathrm{dl}^{-1}\right.$, THF, $l=1.0$ $\mathrm{mm}$ ) for (1) poly(ChP) obtained with AIBN in toluene (run 1-2), (2) poly(ChP) obtained with $n$-BuLi in toluene (run 1-9), (3) ChPS [the model compound of poly(ChP)], (4) ChP monomer, and (5) hydrolyzed poly(ChP) [run 5-4] $\left(c=0.05 \mathrm{~g} \mathrm{dl}^{-1}\right.$, methanol, $\left.l=1.0 \mathrm{~mm}\right)$.

ity. The number-average molecular weights $\left(M_{n}\right)$ of poly $(\mathrm{ChP}) \mathrm{s}$ and poly(ChU)s obtained with the radical initiator were $8.3 \times 10^{3}-8.1 \times$ $10^{4}, 9.0 \times 10^{3}-1.5 \times 10^{4}$, respectively. These were higher than those $\left(4.4 \times 10^{3}-8.9 \times 10^{3}\right)$ of $\operatorname{poly}(\mathrm{ChM})^{8} \quad[n=1$ in Scheme 1]. The homopolymerizabilities of maleimides containing a cholesteryl group were higher when the cholesteryl group was situated far from the maleimide ring. The reason for this may be that steric hindrance of a bulky cholesteryl group decreased during the propagation reaction. Specific rotation $\left([\alpha]_{\mathrm{D}}\right)$ and molecular ellipticity $([\theta])$ of poly $(\mathrm{ChP}) \mathrm{s}$ were -21.4 to $-22.6^{\circ},-6.1 \times 10^{2}$ to $-1.1 \times 10^{3} \mathrm{deg} \mathrm{cm}^{2} \mathrm{~d}$ $\mathrm{mol}^{-1}$, respectively. Specific rotation $\left([\alpha]_{\mathrm{D}}\right)$ and molecular ellipticity $([\theta])$ of poly $(\mathrm{ChU}) \mathrm{s}$ were -17.5 to $-18.8^{\circ},-5.8 \times 10^{2}$ to $-1.3 \times$

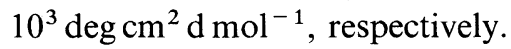

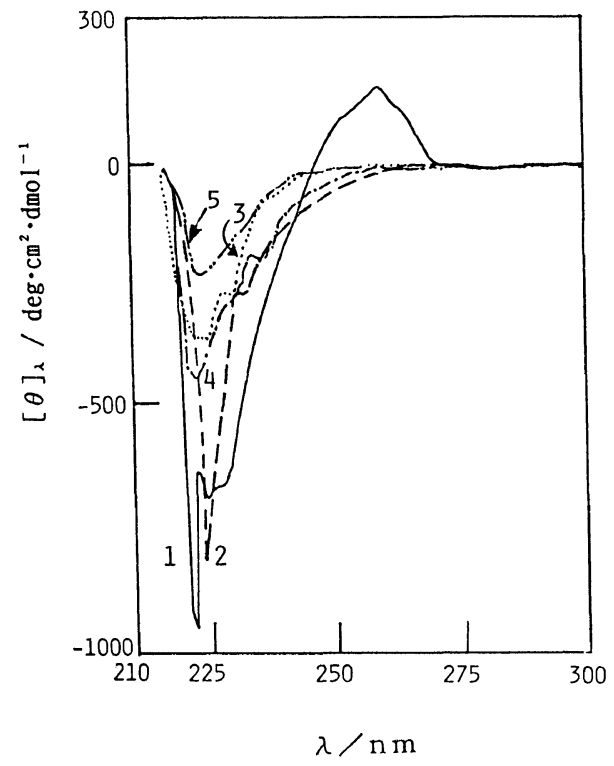

Figure 2. $\mathrm{CD}$ spectra $\left(c=0.1-0.01 \mathrm{~g} \mathrm{dl}^{-1}\right.$, THF, $l=1.0$ $\mathrm{mm}$ ) for (1) poly(ChU) obtained with AIBN in THF (run 2-2), (2) poly(ChU) obtained with $n$-BuLi in THF (run 2-9), (3) ChUS [the model compound for poly(ChU)], (4) ChU monomer, and (5) hydrolyzed poly(ChU) [run 5-5] $\left(c=0.05 \mathrm{~g} \mathrm{dl}^{-1}\right.$, methanol, $\left.l=1.0 \mathrm{~mm}\right)$.

The CD spectra of poly(ChP) and poly(ChU) obtained with AIBN and $n$-BuLi in toluene are shown in Figures 1 and 2. The CD patterns for poly $(\mathrm{ChP})$ and poly(ChU) obtained with AIBN in other solvents were similar to those of the poly $(\mathrm{ChP})$ and poly $(\mathrm{ChU})$ obtained in toluene. In the poly(ChP) and poly(ChU) obtained with AIBN, some large negative and a small positive $C D$ peaks were observed at about $225 \mathrm{~nm}$ and $260 \mathrm{~nm}$, respectively. All peaks were attributed to the $n \rightarrow \pi^{*}$ transition of three carbonyl groups in the maleimide unit. In the polymer obtained with AIBN, the CD peak indicated a positive Cotton effect at 260 $\mathrm{nm}$. This was also observed in poly $(\mathrm{ChM}) \mathrm{s}^{8}$ In poly(ChP) and poly(ChU) obtained with $n$-BuLi, CD peaks at about $260 \mathrm{~nm}$ could hardly be observed. This is quite different from that of $\operatorname{poly}(\mathrm{ChM})^{8}[n=1$ in Scheme 1]. That is, in the CD curves for poly(ChM), a large negative peak at $260 \mathrm{~nm}$ was observed. It is difficult to explain the different $C D$ patterns. 
Table III. Specific rotations $\left([\alpha]_{\mathrm{D}}^{25}\right)$ of the monomer model compound and homopolymer

\begin{tabular}{|c|c|c|c|c|c|c|c|c|}
\hline & \multirow[b]{2}{*}{$\left(\mathrm{CH}_{2}\right)_{\mathrm{n}}$} & \multicolumn{3}{|c|}{ Specific rotations $\left([\alpha]_{\mathrm{D}}^{25}\right)$} & \multirow{2}{*}{$\begin{array}{r}\text { (deg.) } \\
\text { Initiator }\end{array}$} & \multirow[b]{2}{*}{$(A)-(B)$} & \multirow{2}{*}{$\frac{(\mathrm{A})-(\mathrm{B})}{(\mathrm{A})}$} & \multirow[b]{2}{*}{ Ref } \\
\hline & & Monomer & $\begin{array}{l}\text { Model } \\
\text { compound } \\
\text { (A) }\end{array}$ & $\begin{array}{l}\text { Homo- } \\
\text { polymer } \\
\text { (B) }\end{array}$ & & & & \\
\hline ChM & 1 & -27.8 & -26.8 & $\begin{array}{l}-26.1(\mathrm{Tol})^{\mathrm{a}} \\
-40.1(\mathrm{Tol})\end{array}$ & $\begin{array}{l}\text { AIBN } \\
\text { BuLi }\end{array}$ & $\begin{array}{r}0.7 \\
13.3\end{array}$ & $\begin{array}{r}2.7 \\
49.6\end{array}$ & $\begin{array}{l}8 \\
8\end{array}$ \\
\hline $\mathrm{ChP}$ & 5 & -22.1 & -21.3 & $\begin{array}{l}-22.8(\mathrm{Tol}) \\
-24.4(\mathrm{Tol})\end{array}$ & $\begin{array}{l}\text { AIBN } \\
\text { BuLi }\end{array}$ & $\begin{array}{l}1.5 \\
3.1\end{array}$ & $\begin{array}{c}7.0 \\
14.6\end{array}$ & $\begin{array}{l}\text { This work } \\
\text { This work }\end{array}$ \\
\hline $\mathrm{ChU}$ & 11 & -18.9 & -19.4 & $\begin{array}{l}-18.7(\mathrm{Tol}) \\
-19.4(\mathrm{Tol})\end{array}$ & $\begin{array}{l}\text { AIBN } \\
\text { BuLi }\end{array}$ & $\begin{array}{l}0.7 \\
0.0\end{array}$ & $\begin{array}{l}3.6 \\
0.0\end{array}$ & $\begin{array}{l}\text { This work } \\
\text { This work }\end{array}$ \\
\hline
\end{tabular}

a Tol, Polymerization solvent is toluene.

However, the polymers may contain different conformations and configurations of the main chain.

The ${ }^{1} \mathrm{H}$ NMR and ${ }^{13} \mathrm{C}$ NMR spectra for polymers obtained with AIBN or $n$-BuLi were slightly different. On the basis of the differences, it may be difficult to discuss structural differences. The IR spectra for both polymers were the same. No olefinic proton resonance was seen in the ${ }^{1} \mathrm{H}$ NMR spectra for the polymers, which suggests that ordinary addition polymerization proceeded.

The CD patterns for poly(ChP) and poly(ChU) were different from those for the corresponding model compounds, i.e., ChPS and ChUS. This suggests that the chiroptical properties of both polymers obtained with AIBN and $n$-BuLi may be influenced not only by $N$-substituent, a chiral cholesteryl group, but also by other chiral factors. The factors may be as follows: (A) formation of stereogenic centers in the main chain and (B) asymmetric perturbation of the side chain chromophores. Factor (A) contains (i) helical conformation of the main chain, (ii) asymmetric induction around both terminal ChP (or ChU) polymers, and (iii) excess of chiral centers of $(R, R)$ or $(S, S)$ in the polymer main chains, as reported previously. ${ }^{8}$ The asymmetric perturbation of the side chain chromophores is discussed by Wulff et al. ${ }^{11}$ and Farina. ${ }^{12}$

As reported previously, other chiral factors in the ChM ( $n=1$ in Scheme I) appear present by the fact that the optical rotations of the $\mathrm{ChM}$ monomer and model of poly $(\mathrm{ChM})$ were $-26.8^{\circ}$ and $-27.8^{\circ}$, respectively, as shown in Table III. That is, if optical activity is due to only an optically active cholesteryl group, the resulting polymer may indicate about $-27^{\circ}$ of $[\alpha]_{\mathrm{D}}$. A difference $\left(\mathrm{B}-\mathrm{A}=13.3^{\circ}\right.$ in Table III) of specific rotation between the polymer obtained anionically and model of poly $(\mathrm{ChM})$ was actually observed.

In poly(ChP) and poly(ChU), differences $\left(\mathrm{B}-\mathrm{A}=-3.1^{\circ}\right.$ for $\operatorname{poly}(\mathrm{ChP}) ; \mathrm{B}-\mathrm{A}=0^{\circ}$ for poly $(\mathrm{ChU})$ in Table III) were less than for poly $(\mathrm{ChM})$. That is, when the methylene unit became longer, differences $(B-A)$ gradually decreased. This suggests that chiroptical properties are significantly influenced by the distance from the reacting maleimide ring to the optically active group; i.e., length of the methylene units. This was particularly evident in anionic polymerizations.

\section{Radical Copolymerizations of ChP (or ChU) with $S T$ ( or MMA)}

The results of radical copolymerizations of $\mathrm{ChP}$ and $\mathrm{ChU}\left(\mathrm{M}_{1}\right)$ with ST $\left(\mathrm{M}_{2}\right)$, MMA $\left(\mathrm{M}_{2}\right)$ in benzene $(2 \mathrm{ml})$ at $60^{\circ} \mathrm{C}$ in the presence of AIBN $\left(1.0 \times 10^{-2} \mathrm{moll}^{-1}\right)$ are shown in Tables IV and V. All copolymerizations proceeded homogeneously throughout. The resulting copolymers were colorless powders and opti- 
T. OISHI et al.

Table IV. Radical copolymerization of $\mathrm{ChP}\left(\mathrm{M}_{1}\right)$ with ST $\left(\mathrm{M}_{2}\right)$ or $\mathrm{MMA}\left(\mathrm{M}_{2}\right)$ in toluene $(2 \mathrm{ml})$ at $60^{\circ} \mathrm{C}^{\mathrm{a}}$

\begin{tabular}{|c|c|c|c|c|c|c|c|c|}
\hline \multirow{2}{*}{ Run } & \multirow{2}{*}{$\mathrm{M}_{2}$} & \multirow{2}{*}{$\begin{array}{c}\begin{array}{c}\mathrm{M}_{1} \text { in } \\
\text { monomer }\end{array} \\
\mathrm{mol} \%\end{array}$} & \multirow{2}{*}{$\frac{\text { Convn. }}{\%}$} & \multirow{2}{*}{$\frac{\begin{array}{c}\mathrm{M}_{1} \text { in } \\
\text { copolymer }^{\mathrm{b}}\end{array}}{\mathrm{mol} \%}$} & \multirow{2}{*}{$\frac{\bar{M}_{n}^{\mathrm{c}}}{\times 10^{-4}}$} & \multirow{2}{*}{$\bar{M}_{n} / \bar{M}_{w}$} & \multirow{2}{*}{$\frac{[\alpha]_{\mathrm{D}}^{25 \mathrm{~d}}}{\operatorname{deg} .}$} & \multirow{2}{*}[\theta]{$_{\lambda}^{\mathbf{e}}$} \\
\hline & & & & & & & & \\
\hline $3-1$ & ST & 10.5 & 15.3 & 36.5 & 21.6 & 1.68 & -14.2 & -141 \\
\hline $3-2$ & ST & 20.0 & 13.1 & 39.1 & 22.4 & 1.65 & -16.7 & -231 \\
\hline $3-3$ & ST & 37.0 & 22.0 & 46.3 & - & - & -17.5 & -450 \\
\hline $3-4$ & ST & 48.0 & 22.3 & 56.0 & - & - & -16.6 & -329 \\
\hline $3-5$ & ST & 60.0 & 25.9 & 56.7 & - & - & -17.2 & -593 \\
\hline $3-6$ & ST & 79.2 & 13.8 & 63.6 & 3.7 & 2.04 & -18.7 & -599 \\
\hline $3-7$ & ST & 90.0 & 17.2 & 86.6 & 2.5 & 1.98 & -20.5 & -548 \\
\hline $3-8$ & MMA & 10.0 & 14.3 & 12.6 & 2.8 & 1.69 & -6.0 & -201 \\
\hline $3-9$ & MMA & 19.0 & 13.8 & 14.9 & 6.4 & 1.77 & -9.2 & -131 \\
\hline $3-10$ & MMA & 40.1 & 23.8 & 40.2 & 6.4 & 1.70 & -15.3 & -346 \\
\hline $3-11$ & MMA & 50.0 & 29.0 & 45.2 & 4.6 & 1.90 & -18.5 & -348 \\
\hline $3-12$ & MMA & 59.0 & 26.5 & 59.2 & 3.0 & 2.11 & -19.1 & -483 \\
\hline $3-13$ & MMA & 78.0 & 25.1 & 68.5 & 2.3 & 1.54 & -20.6 & -599 \\
\hline $3-14$ & MMA & 91.5 & 14.1 & 87.5 & 1.9 & 1.88 & -20.3 & -533 \\
\hline
\end{tabular}

${ }^{\mathrm{a}}[\mathrm{AIBN}]=1.0 \times 10^{-2} \mathrm{moll}^{-1} ; \mathrm{M}_{1}+\mathrm{M}_{2}=1.0 \mathrm{~g} ; \mathrm{ChP}-\mathrm{ST}$, run 3-1-3-7; ChP-MMA, run 4-8-4-14; polymerization time, $10 \mathrm{~h}$.

b Calculated from ${ }^{1} \mathrm{H}$ NMR spectra.

c Estimated by GPC.

d $c=1.0 \mathrm{~g} \mathrm{dl}^{-1}, l=5.0 \mathrm{~cm} ;$ THF.

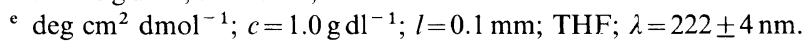

Table V. Radical copolymerization of $\mathrm{ChU}\left(\mathrm{M}_{1}\right)$ with ST $\left(\mathrm{M}_{2}\right)$ or MMA $\left(\mathrm{M}_{2}\right)$ in toluene $(2 \mathrm{ml})$ at $60^{\circ} \mathrm{C}^{\mathrm{a}}$

\begin{tabular}{|c|c|c|c|c|c|c|c|c|}
\hline \multirow{2}{*}{ Run } & \multirow{2}{*}{$\mathrm{M}_{2}$} & \multirow{2}{*}{$\frac{\begin{array}{c}\mathrm{M}_{1} \text { in } \\
\text { monomer }\end{array}}{\mathrm{mol}^{2} \%}$} & \multirow{2}{*}{$\frac{\text { Convn. }}{\%}$} & \multirow{2}{*}{$\frac{\begin{array}{c}\mathrm{M}_{1} \text { in }^{\mathrm{b}} \\
\text { copolymer }\end{array}}{\mathrm{mol} \%}$} & \multirow{2}{*}{$\frac{\bar{M}_{n}^{\mathrm{c}}}{\times 10^{-4}}$} & \multirow{2}{*}{$\bar{M}_{n} / \bar{M}_{w}$} & \multirow{2}{*}{$\frac{[\alpha]_{\mathrm{D}}^{25 d}}{\operatorname{deg} .}$} & \multirow{2}{*}[\theta]{$_{\lambda}^{\mathbf{e}}$} \\
\hline & & & & & & & & \\
\hline $4-1$ & ST & 4.8 & 15.7 & 14.0 & 9.6 & 2.63 & -12.8 & -116 \\
\hline $4-2$ & ST & 9.8 & 22.0 & 26.9 & 13.8 & 2.67 & -14.7 & -321 \\
\hline $4-3$ & ST & 29.8 & 32.3 & 49.3 & 16.8 & 5.60 & -15.1 & -217 \\
\hline $4-4$ & ST & 48.7 & 20.8 & 56.5 & 12.2 & 2.24 & -16.9 & -469 \\
\hline $4-5$ & ST & 69.1 & 21.7 & 66.5 & 4.8 & 3.49 & -16.5 & -382 \\
\hline $4-6$ & ST & 89.9 & 13.2 & 80.4 & 1.3 & 2.70 & -17.5 & -696 \\
\hline $4-7$ & MMA & 5.0 & 10.5 & 3.0 & 1.5 & 8.29 & -1.9 & -66 \\
\hline $4-8$ & MMA & 9.8 & 21.2 & 7.1 & 8.0 & 1.90 & -6.3 & -74 \\
\hline 49 & MMA & 29.5 & 22.3 & 25.0 & 2.8 & 3.06 & -10.6 & -184 \\
\hline $4-10$ & MMA & 51.0 & 19.2 & 46.8 & 2.9 & 2.54 & -14.6 & -198 \\
\hline $4-11$ & MMA & 70.2 & 20.3 & 57.8 & 1.9 & 2.38 & -15.3 & -353 \\
\hline $4-12$ & MMA & 88.7 & 17.7 & 76.8 & 1.8 & 1.25 & -18.0 & -486 \\
\hline
\end{tabular}

${ }^{\mathrm{a}}[\mathrm{AIBN}]=1.0 \times 10^{-2} \mathrm{moll}^{-1} ; \mathrm{M}_{1}+\mathrm{M}_{2}=1.0 \mathrm{~g} ; \mathrm{ChU}-\mathrm{ST}$, run 4-1-4-6; ChU-MMA, run 4-7-4-12; polymerization time, $10 \mathrm{~h}$.

${ }^{\mathrm{b}}$ Calculated from ${ }^{1} \mathrm{H}$ NMR spectra.

c Estimated by GPC.

d $c=1.0 \mathrm{~g} \mathrm{dl}^{-1}, l=5.0 \mathrm{~cm} ; \mathrm{THF}$.

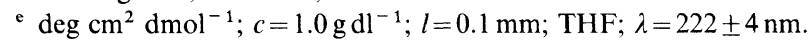




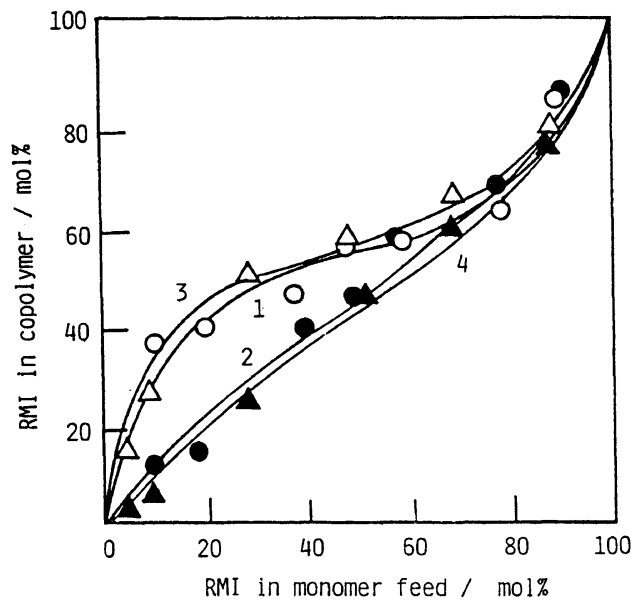

Figure 3. Copolymer composition curves for (1) the ChP-ST, (2) ChP-MMA, (3) ChU-ST, and (4) ChU-MMA systems.

Table VI. Monomer reactivity ratios and Alfrey-Price $Q-e$ values

\begin{tabular}{lcccccc}
\hline $\mathrm{M}_{1}$ & $\mathrm{M}_{2}$ & $r_{1}$ & $r_{2}$ & $Q_{1}$ & $e_{1}$ & ref \\
\hline $\mathrm{ChM}$ & $\mathrm{ST}$ & 0.09 & 0.08 & 2.07 & 1.2 & 8 \\
$\mathrm{ChP}$ & $\mathrm{ST}$ & 0.24 & 0.11 & 2.02 & 1.12 & This work \\
$\mathrm{ChU}$ & $\mathrm{ST}$ & 0.39 & 0.11 & 2.18 & 0.97 & This work \\
ChM & MMA & 0.13 & 1.22 & 1.04 & 1.76 & 8 \\
ChP & MMA & 0.40 & 0.83 & 1.37 & 1.46 & This work \\
ChU & MMA & 0.38 & 0.80 & 1.43 & 1.49 & This work \\
\hline
\end{tabular}

cally active.

Copolymer-composition curves of the ChPST, ChP-MMA, ChU-ST, and ChU-MMA systems are shown in Figure 3. Monomer reactivity ratios, $r_{1}$ and $r_{2}$ determined according to the high conversion method reported by Tüdös and co-workers ${ }^{13}$, and Alfrey and Price $^{14} Q, e$ are shown in Table VI. These copolymerization parameters were similar to those for other RMI copolymers reported previously. ${ }^{15}$

\section{Optical Behavior of the Copolymers}

Figure 4 shows the relation between specific rotations and content $(\mathrm{wt} \%)$ of the monomeric unit of $\mathrm{ChP}$ in both copolymer systems. Absolute specific rotations of a just mixture of poly(ChP) and poly(ST) gave a good linear

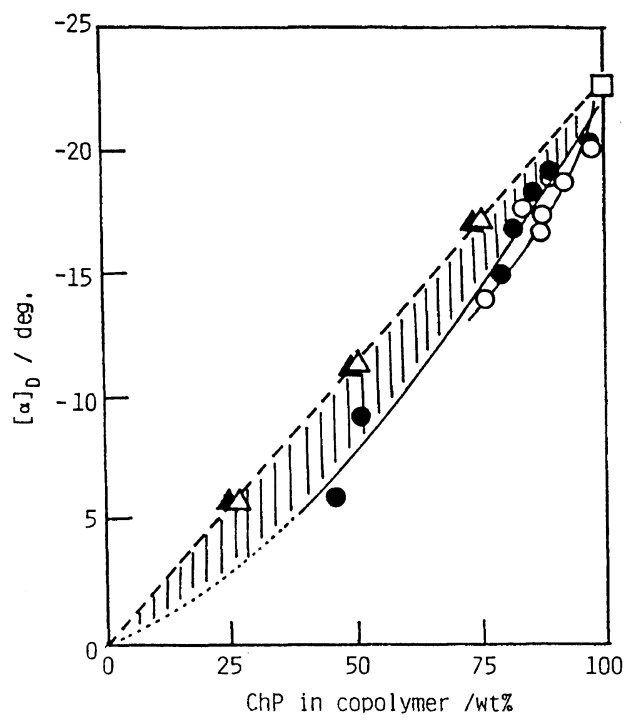

Figure 4. Relationships between specific rotation $[\alpha]_{D}$ and content of the monomeric unit of $\mathrm{ChP}$ in copolymers: (O) $\operatorname{poly}(\mathrm{ChP}-c o-\mathrm{ST}) \mathrm{s},(\bigcirc) \operatorname{poly}(\mathrm{ChP}-c o-\mathrm{MMA}) \mathrm{s},(\triangle)$ a mixture of poly $(\mathrm{ChP})$ and poly(ST), $(\mathbf{\Delta})$ a mixture of poly(ChP) and poly(MMA), and ( $\square$ ) poly(ChP) [run 1-2].

relationship, as shown in Figure $4(\triangle)$. The absolute specific rotations of poly(ChP-co-ST)s increased with the content $(\mathrm{wt} \%)$ of the $\mathrm{ChP}$ unit. However, some deviation from linearity was observed, which suggests that stereogenic centers in the main chain were formed, (that is, asymmetric induction occurred in the main chain of the copolymers), and that asymmetric perturbation $^{11,12}$ of the side chain chromophores took place. In poly(ChP-co-MMA)s, the same was observed, as shown in Figure 4. This indicates that the chiroptical properties of the ChP copolymers can be influenced by the comonomer; ST, MMA. In ChM $(n=1)$, deviation was present above a straight line. But in ChP $(n=5)$ deviation was under a straight line. The length of methylene units, (distance from a maleimide ring to a cholesteryl group) influenced the specific rotations of the copolymers. It is of interest that the effect was observed even though an asymmetric carbon in $\mathrm{ChP}$ was far from a maleimide ring. In this case the number of methylene units was between maleimide ring and cholesteryl group is 5 . 


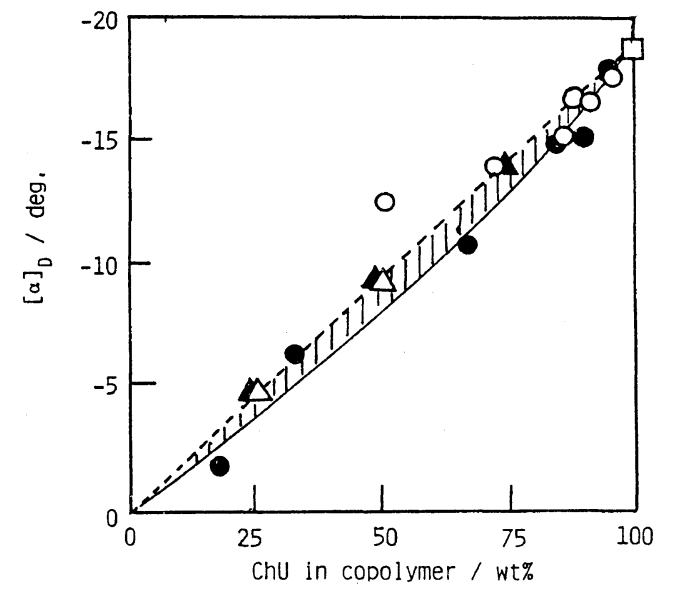

Figure 5. Relationships between specific rotation $[\alpha]_{D}$ and content of the monomeric unit of $\mathrm{ChU}$ in copolymers: (○) poly(ChU-co-ST)s, (O) poly(ChU-co-MMA)s, $(\triangle)$ a mixture of poly(ChU) and poly(ST), ( $\mathbf{\Delta})$ a mixture of poly(ChU) and poly(MMA), and $(\square)$ poly(ChU) [run 2-2].

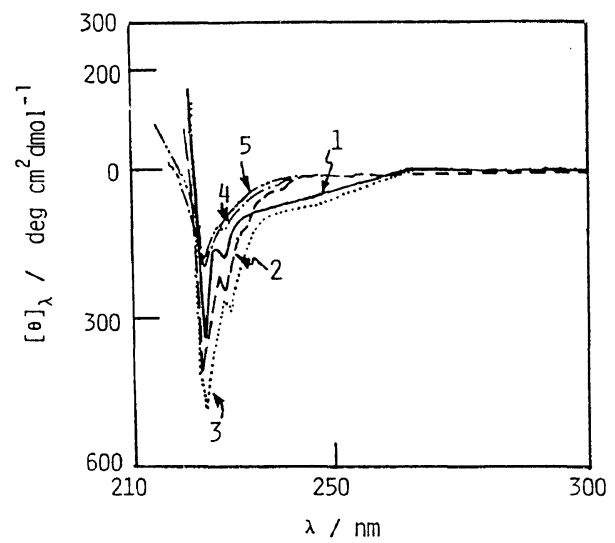

Figure 6. $\mathrm{CD}$ spectra $\left(c=0.1-0.01 \mathrm{~g} \mathrm{dl}^{-1}\right.$, THF, $l=1.0$ $\mathrm{mm}$ ) for (1) poly(ChP-co-ST)[run 3-4], (2) poly(ChP-coMMA) [run 3-11], (3) poly(ChU-co-ST) [run 4-4], (4) poly(ChU-co-MMA) [run 4-10], and (5) hydrolyzed poly(ChP-co-ST) [run 5-6] $\left(c=0.05 \mathrm{~g} \mathrm{dl}^{-1}\right.$, methanol, $l=$ $1.0 \mathrm{~mm}$ )

The relation between specific rotation and content $(\mathrm{wt} \%)$ of the monomeric unit of $\mathrm{ChU}$ in both copolymer systems is shown in Figure 5. In ChU systems, similar tendencies were also observed. However, the deviation from linearity was less than that in ChP systems, which suggests that asymmetric induction into the
Table VII. Optical behavior of hydrolyzed polymers

\begin{tabular}{|c|c|c|c|c|c|}
\hline \multirow{3}{*}{ Run } & \multicolumn{3}{|c|}{ Original polymers $^{\mathrm{a}}$} & \multicolumn{2}{|c|}{ Hydrolyzed polymers } \\
\hline & & {$[\alpha]_{\mathrm{D}}$} & {$[\theta]_{\lambda}$} & {$[\alpha]_{D}^{b}$} & {$[\theta]_{\lambda}^{\mathrm{c}}$} \\
\hline & Run & deg & $\begin{array}{l}\operatorname{deg} \mathrm{cm}^{2} \\
\mathrm{dmol}^{-1}\end{array}$ & deg & $\begin{array}{l}\operatorname{deg} \mathrm{cm}^{2} \\
\mathrm{dmol}^{-1}\end{array}$ \\
\hline $5-1$ & $A-1^{d}$ & -25.9 & -680 & -1.1 & -220 \\
\hline $5-2$ & $\mathrm{C}-2^{\mathrm{d}}$ & -23.9 & -290 & -1.5 & -180 \\
\hline $5-3$ & $D-2^{d}$ & -20.0 & - & -0.8 & -140 \\
\hline $5-4$ & $1-4$ & -22.0 & -660 & -1.3 & -230 \\
\hline $5-5$ & $2-4$ & -18.2 & -699 & -1.4 & -200 \\
\hline $5-6$ & $3-3$ & -17.5 & -450 & -1.6 & -180 \\
\hline $5-7$ & $3-10$ & -15.3 & -346 & -1.4 & -170 \\
\hline $5-8$ & $4-3$ & -15.1 & -217 & -1.1 & - \\
\hline $5-9$ & $4-9$ & -10.6 & -184 & -1.0 & - \\
\hline
\end{tabular}

a See run no. in Tables I, II, IV, and V.

b. $c=0.5 \mathrm{~g} \mathrm{dl}^{-1} ; l=5 \mathrm{~cm}$; in methanol.

c $c=0.05 \mathrm{~g} \mathrm{dl}^{-1} ; l=1.0 \mathrm{~mm}$; in methanol; $\lambda=220 \pm 3$ $\mathrm{nm}$.

${ }^{d}$ See run no. in Tables I and III reported previously. ${ }^{8}$

copolymer main chain and asymmetric perturbation of the side chain chromophores are smaller. Chiroptical properties were significantly influenced by length of the methylene units connected to the optically active group.

In the CD spectra for poly(ChP-co-ST) and poly(ChU-co-ST), as shown in Figure 6, a weak and a strong negative peaks were observed around 250 and $225 \mathrm{~nm}$, respectively. Both peaks were ascribed to the $\pi \rightarrow \pi^{*}$ transition of phenyl groups of ST unit and to the $n \rightarrow \pi^{*}$ transition of carbonyl groups of ChP (or ChU) unit. In the $\mathrm{CD}$ spectra for poly(ChP-coMMA) and poly(ChU-co-MMA), two negative peaks were observed at about $250 \mathrm{~nm}$, based on the $n \rightarrow \pi^{*}$ transition of carbonyl groups of MMA and ChP (or ChU) units, as shown in Figure 6.

To confirm asymmetric induction, the polymers and copolymers were hydrolyzed in a mixture of THF and methanol saturated with potassium hydroxide. As shown in Table VII, the specific rotations of the hydrolyzed polymers and copolymers were very small, but still optically active after hydrolysis. A very 


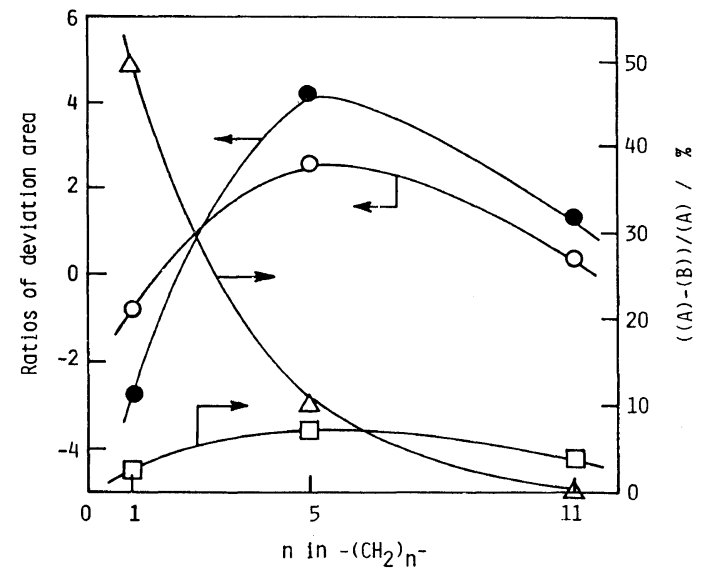

Figure 7. Relationships between the number of methylene units and ratios of the deviation area (shaded portion in Figure 4 and 5) [(-) show opposite deviation of $(+)]$, and $((\mathrm{A})-(\mathrm{B})) /(\mathrm{A})$ data in Table III: $(\mathrm{O})$, ST copolymers, (○), MMA copolymers, ( $\square$ ), polymers obtained with AIBN, and $(\triangle)$, polymers obtained with $n$-BuLi.

small negative peak was observed in $C D$ spectra, as shown in Figures 1, 2, and 6, thus confirming that asymmetric induction into the polymers and copolymers surely took place. The specific rotations of the hydrolyzed polymers and copolymers indicated similar values regardless of methylene unit length. Asymmetric induction (i.e., formation of stereogenic centers) may thus be due to the chiral factors (A: i, ii, and iii) described above.

Relationships between the number of methylene units and ratios of deviation area $[(-)$ show opposite deviation of $(+)]$, and $((\mathrm{A})-(\mathrm{B})) /(\mathrm{A})$ values in Table III are shown in Figure 7. For MMA systems, a deviation area indicates shaded portion in Figures 4 and 5. As can be seen from Figure 7, the optical activities of the original polymers and copolymers before hydrolysis were significantly influenced by the lengths of methylene units connected to the optically active cholesteryl groups. When the number of methylene units was 1, the deviation from a linear line was present on the opposite side. Specific rotations of all hydrolyzed polymers and copolymers were very small and negative, as shown in Table
VII. Thus, it was considered that asymmetric perturbation of the side chain chromophore played an important role in the optical properties of the original copolymers. In anionic polymerizations, the length of a methylene unit influences the chiroptical properties of the polymers.

\section{CONCLUSIONS}

(1) Novel optically active $N$-(cholesteroxycarbonyl- $n$-pentyl)maleimide (ChP) and $N$ (cholesteroxycarbonyl- $n$-undecyl)maleimide (ChU) were synthesized and polymerized with radical and anionic initiators to obtain chiral polymers.

(2) From the results of the radical copolymerizations of $\mathrm{ChP}\left(\mathrm{M}_{1}\right)$ or $\mathrm{ChU}\left(\mathrm{M}_{1}\right)$ with $\operatorname{ST}\left(\mathrm{M}_{2}\right)$ or MMA $\left(\mathrm{M}_{2}\right)$, monomer reactivity ratios $\left(r_{1}, r_{2}\right)$ and $Q-e$ were determined as follows: $r_{1}=0.24, r_{2}=0.11, Q_{1}=2.02, e_{1}=1.12$ in the ChP-ST system, $r_{1}=0.40, r_{2}=0.83$, $Q_{1}=1.37, e_{1}=1.46$ in the ChP-MMA system, $r_{1}=0.39, r_{2}=0.11, Q_{1}=2.18, e_{1}=0.97$ in the ChU-ST system, $r_{1}=0.38, r_{2}=0.80, Q_{1}=1.43$, $e_{1}=1.49$ in the ChU-MMA system.

(3) Chiroptical properties for the polymers and copolymers were significantly influenced by length of the methylene units.

(4) Asymmetric induction polymerization and copolymerization took place to a slight extent in all systems. This was confirmed by the fact that hydrolyzed polymers and copolymers still had optical activity.

(5) All hydrolyzed polymers and copolymers had similar specific rotations, and the values were very smali.

(6) The chiroptical properties of the original polymers and copolymers were significantly influenced by asymmetric perturbation of the side chain chromophore. This effect decreased as the length of the methylene units became longer.

Acknowledgements. We are indebted to Mr. M. Momoi for conducting the elemental 
analysis.

\section{REFERENCES}

1. Y. S. Freidzon, Y. G. Tropsha, V. P. Shibaev, and N. A. Plate, Makromol. Chem., Rapid Commun., 6, 625 (1985).

2. T. Yamaguchi, T. Hayashi, and N. Nakamura, Mol. Cryst. Liq. Cryst., 5, 23 (1987).

3. G. M. Janini, R. J. Laub, and T. J. Shaw, Makromol. Chem., Rapid Commun., 6, 57 (1985).

4. M. L. Tsai and S. H. Chen, Macromolecules, 23, 1908 (1990).

5. Y. S. Freidzon, N. I. Boiko, V. P. Shibaev, and N. A. Plate, Eur. Polym. J., 22, 13 (1986).

6. For example: H. Finkelmann, H. Ringsdorf, W. Siol, and H. Wendorff, Makromol. Chem., 179, 829(1978).

7. For example: (1) R. C. P. Cubbon, Polymer, 6, 419 (1966); (2) A. Matsumoto, T. Kubota, and T. Otsu,
Macromolecules, 23, 4508 (1990). (3) H. Yamaguchi and Y. Minoura, J. Polym. Sci., A-1, 8, 929, (1970).

8. T. Oishi, Y. Otsubo, and M. Fujimoto, Polym. J., 24, 527 (1992).

9. D. H. Rich and P. D. Gesellchen, J. Med. Sci., 18, 1004 (1975).

10. T. Oishi, K. Kagawa, and M. Fujimoto, submitted to "Macromolecules".

11. M. Farina, Top. Stereochem., 17, 1 (1987).

12. For example, G. Wulff and P. K. Dhal, Macromolecules, 23, 100 (1990); 23, 4525 (1990), 21, 571 (1988).

13. F. Tüdös, T. Kelen, T. Foldes-Berezsnich, and B. Turcsanyi, J. Macromol. Sci.-Chem., A10, 1513 (1976); method 6 was used in this paper.

14. T. Alfrey, Jr. and C. C. Price, J. Polym. Sci., 2, 101 (1947).

15. L. J. Young, "Tabulation of $Q-e$ values," in Polymer Handbook, J. Brandrup and E. H. Immergut, Ed., Wiley, New York, 1975, II-387. 